\title{
Strategi Pemasaran UD. STAR MOTOR \\ Oleh
}

\section{Dian Rasidah}

\section{Pembimbing I Gede Arimbawa}

Berdiri di tahun 1980 di kota Surabaya ini didirikan oleh Tuan Yeffry kelahiran Jember 28 oktober 1954, yang awalnya berada di Jl. Kedung Doro 185 dan sempat beberapa kali pindah yang saat ini untuk kantornya berada di Jl. Wonorejo I 103 , untuk gudang berada di Jl.Wonorejo I 130 , ada pula gudang lain di Tanrise Southgate Jl.nangka seruni gedangan A-26 .

Perusahaan yang bergerak di bidang Onderdil (spare parts) motor ini pada awal berdiri yang di bantu 5 karyawannya hanya memasarkan di wilayah jawa saat memasuki tahun 1990 perusahaan ini baru mulai mencoba memasarkan keluar jawa, dengan usaha , tekat dan kegigihannya perusahaan ini berkembang pesat, hingga jumlah karyawannya saat ini berjumlah 37 karyawan.

Dan sekarang usaha ini di lanjutkan oleh anak ke 2 nya Tuan David Nyoto Gunawan kelahiran Surabaya 7 mei 1983 yang pernah menempuh pendidikan di UNIVERSITY OF BRITISH COLUMBIA, BACHELOR DEGREE BUSINESS ADM “2004”. 


\section{STEAKHOLDERS}

UD. STAR MOTOR
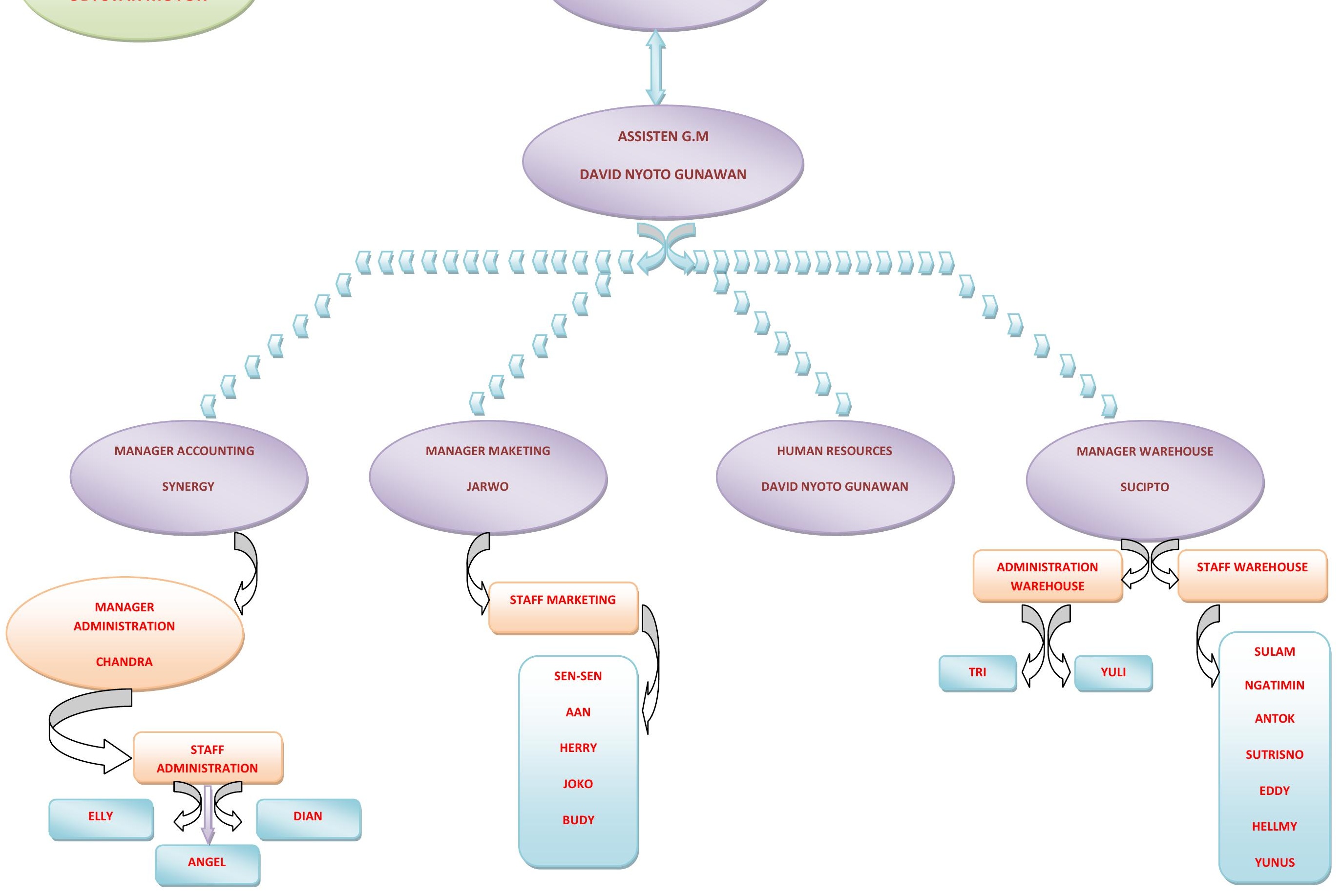

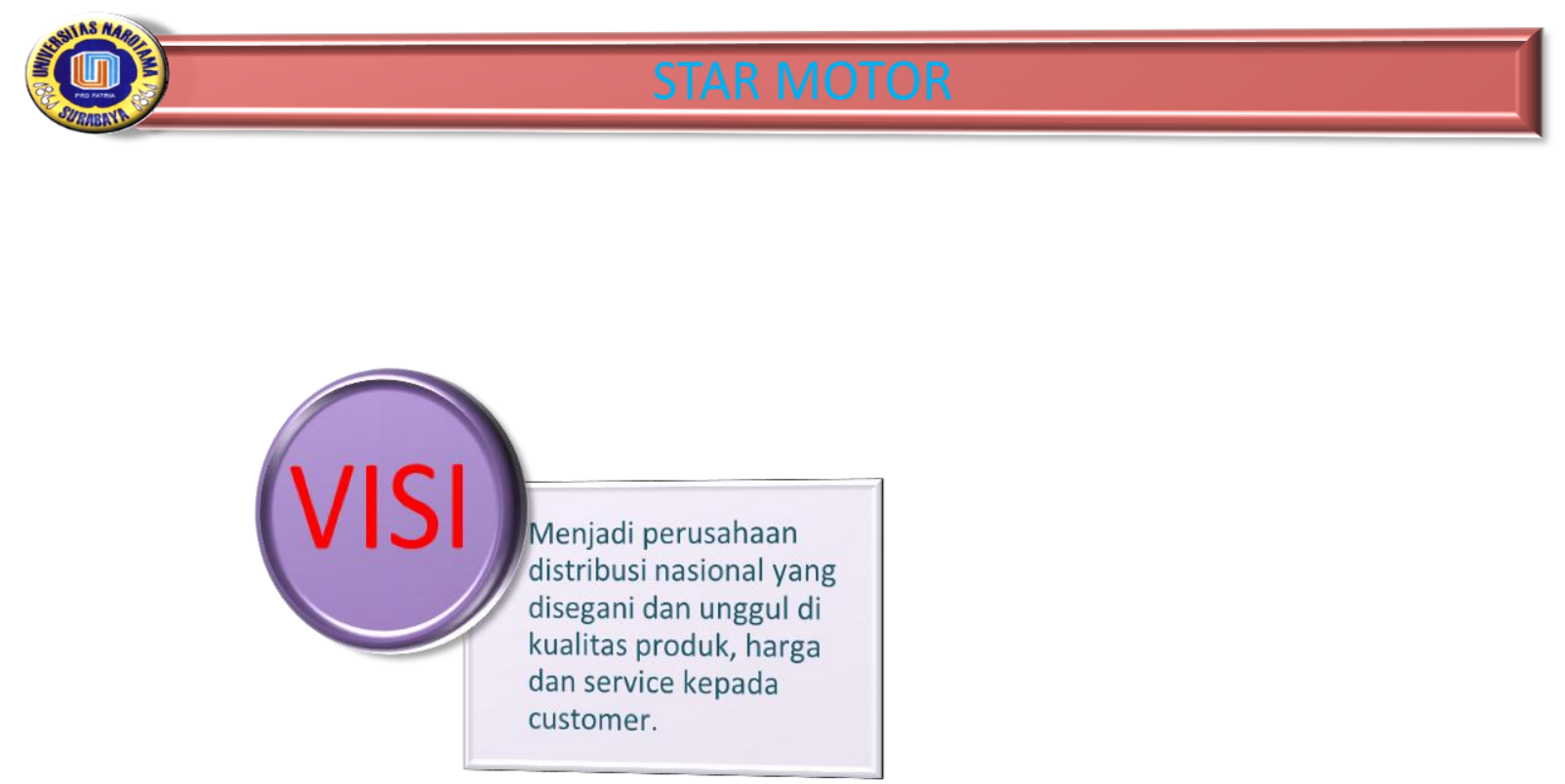

- Mengembangkan jaringan distribusi dan retail ke seluruh Indonesia.

- Menambah varian produk untuk memenuhi kebutuhan pelanggan.

- Mengembangkan SDM yang berkompeten dengan menciptakan lingkungan kerja yang baik untuk mendukung keputusan pelanggan. 


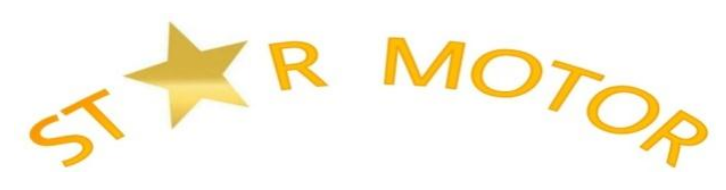

UD. STAR MOTOR

SEGMENTASI PASAR
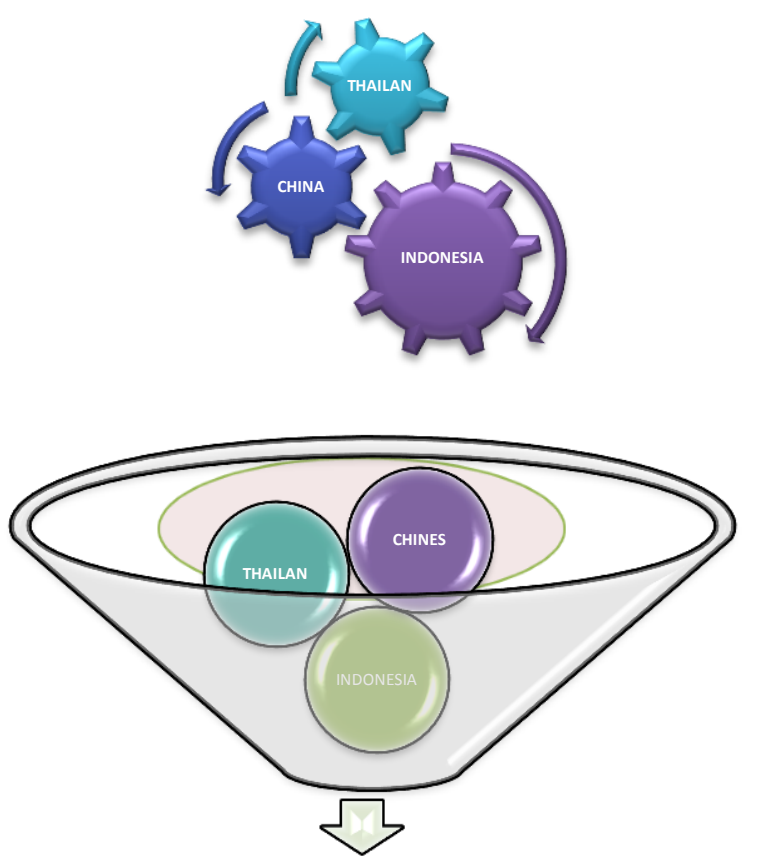

UD . STAR MOTOR 

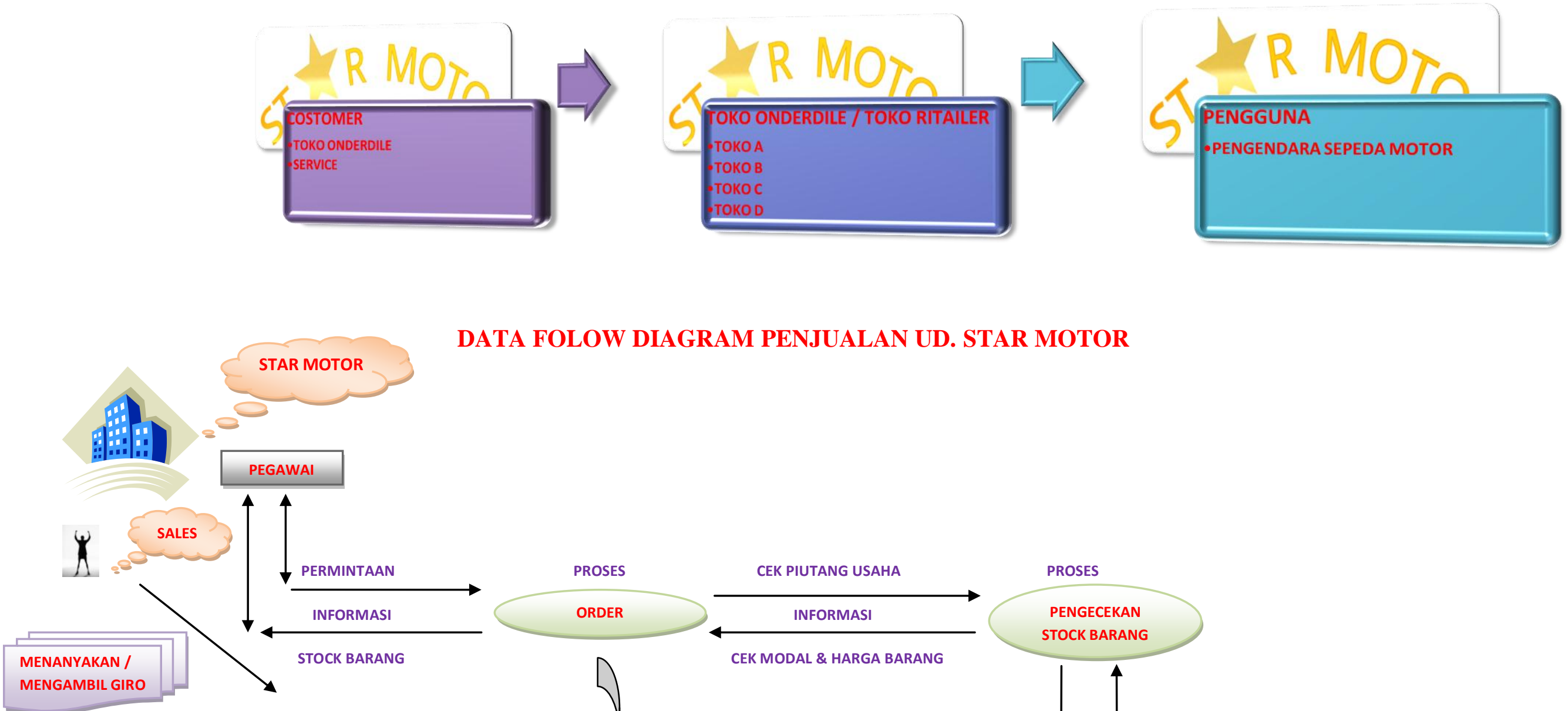

DATA FOLOW DIAGRAM PENJUALAN UD. STAR MOTOR
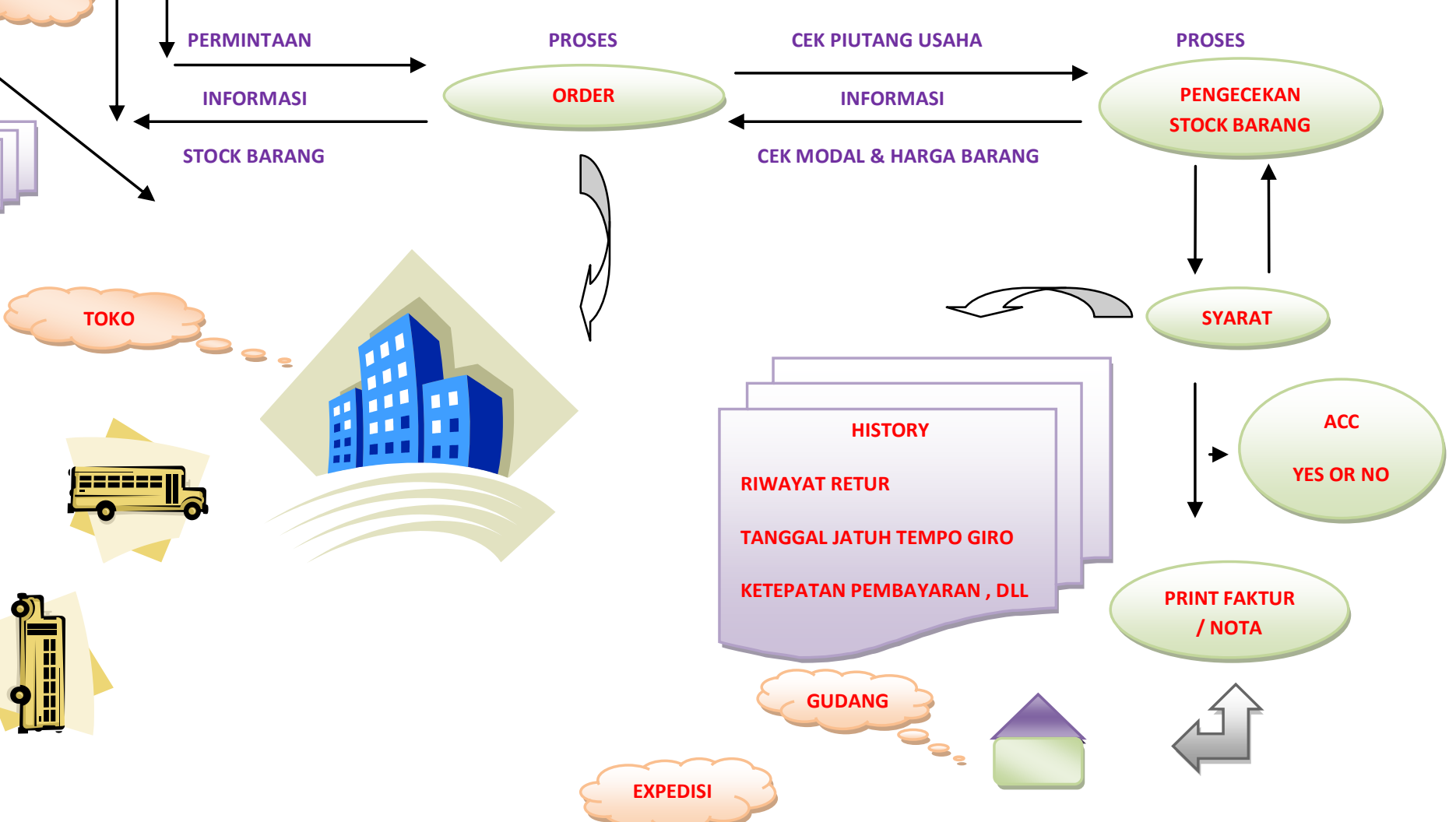


$$
\sqrt{100}
$$$$
\sqrt{1=0}
$$

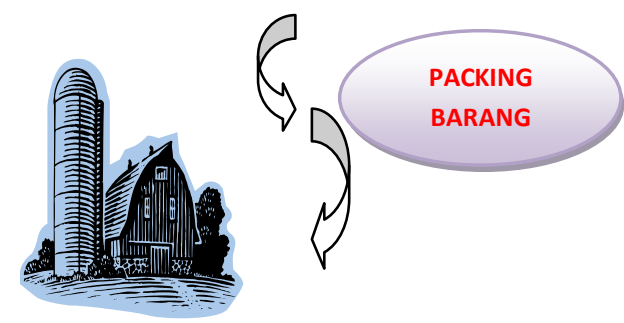


DATA FOLOW DIAGRAM PENGGAJIAN UD. STAR MOTOR

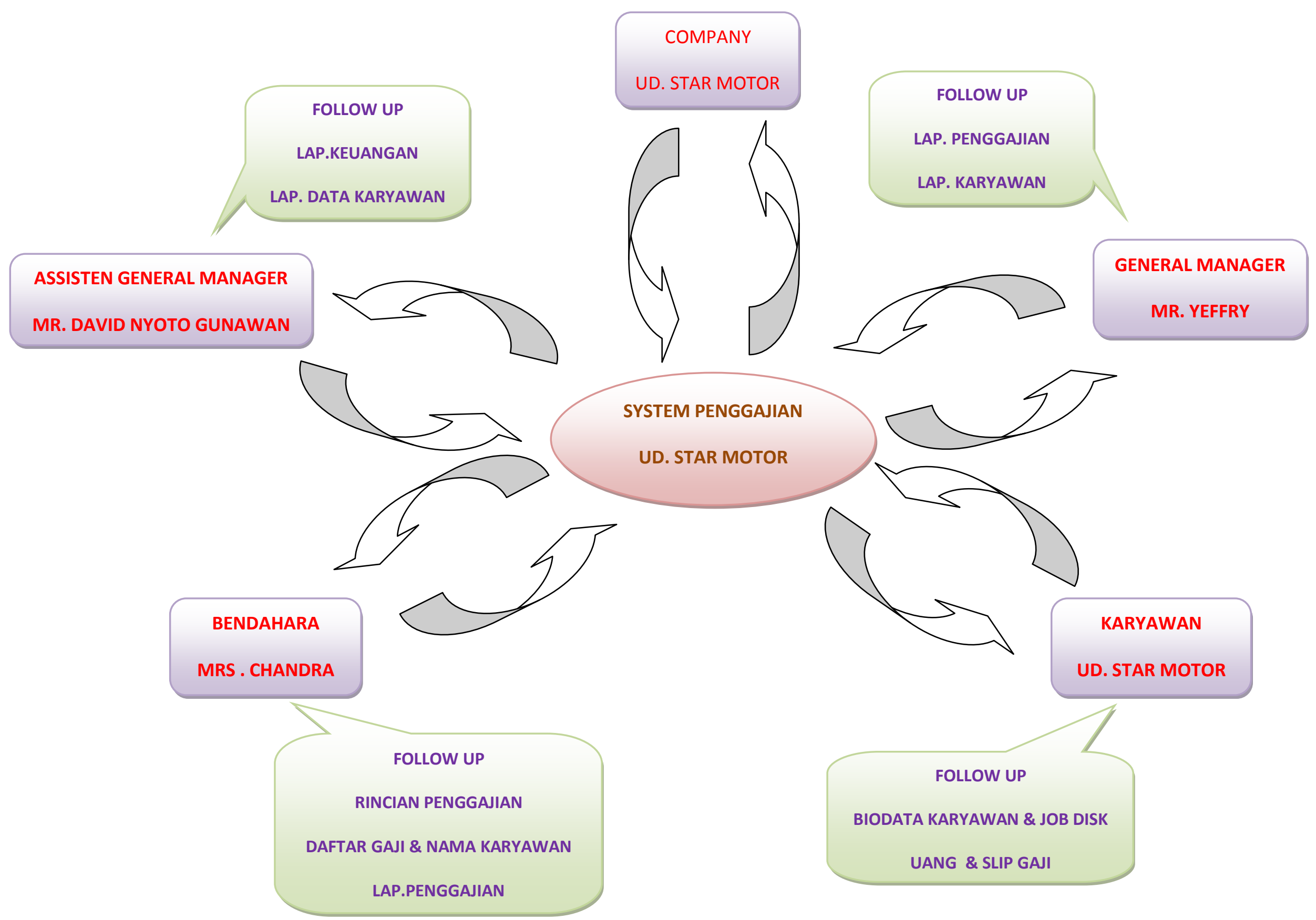




\section{Kode Barang}

Berikut ini beberapa Kode Nama Merek Barang yang di pasarkan oleh UD. STAR MOTOR, tanpa saya sebutkan nama merek aslinya karen itu hak dan privasi dokumen perusahaan.

\begin{tabular}{|lllllll|}
\hline AICH & ASSO & EDWR & GDW & IBI & KKSN & KWTS \\
\hline MHZ & NRB & PRES & MHZ & NRB & PRES & MHZ \\
\hline
\end{tabular}

\section{- Tujuan Perusahaan}

Sebagaimana disebutkan bahwa UD. Star Motor merupakan perusahaan yang bertujuan menjalankan fungsi produksi, penjualan dan pelayanan purna jual yang lengkap untuk kepuasan pelanggan. Artinnya fungsi produksi adalah menciptakan produk untuk dapat di jual, dari penjualan tentunya akan mendapatkan keutungan. Sedangkan purna jual sebenarnya juga merupakan unsur bisnis yang dapat menghasilkan keutungan. Tetapi di lain pihak bahwa produk yang di jual tersebut dapat di manfaatkan secara maximal sebagai alternatif kendaraan transportasi yang murah dan sesuai kebutuhan masyarakat. Dari uraian tersebut tujuan perusahaan untuk mendapat keuntungan dan keinginan konsumen mendapat kepuasan tampak bersinergi.

Mengingat bahwa UD. Star Motor ini menjual semua keperluan Motor ( onderdil ), dari cover body sampai onderdil terkecil (dalam). Sebagaimana disebutkan oleh Bpk. Yeffry bahwa tujuan merupakan titik awal dari perencanaan pemasaran. Tujuan tersebut harus ditetapkan sebelum mengambil keputusan strategis. Tujuan perusahaan pada dasarnya ada 2 yaitu tujuan Umum dan Tujuan khusus. Tujuan umum adalah mencari laba atau keuntungan, sedangkan tujuan khusus adalah terkait dengan upaya peningkatan kualitas produk, perluasan pasar dan laba jangka pendek.

Dari penjelasan dan dasar teori yang ada saya tarik garis besar bahwa memang perusahaan ini berusaha mencari laba atau keuntungan serta berusaha memperkuat/memperluas pemasaran produk. Tetapi juga terdapat tujuan untuk kebaikan konsumen yaitu berupa kepuasan pelanggan itu sendiri. Artinya keuntungan merupakan hasil dari keberhasilan perusahaan mencapai tujuannya.

\section{$>$ Pengertian Manajemen Pemasaran}

Definisi manajemen pemasaran menurut (Kotler, P., \& Keller, 2009)manajemen pemasaran adalah proses perencanaan dan pelaksanaan konsepsi, penentuan harga, promosi dan distribusi barang, jasa dan gagasan untuk menciptakan pertukaran dengan kelompok sasaran yang memenuhi tujuan pelanggan dan organisasi.

\section{> Bauran Pemasaran}

Menurut(Kotler, 2000), Bauran pemasaran adalah suatu perangkat pemasaran yang dapat digunakan oleh perusahaan dalam mencapai tujuan pemasaran dalam target pasarnya.

Bauran pemasaran adalah kombinasi variabel atau kegiatan yang merupakan inti dari sistem pemasaran perusahaan yaitu product, price, promotion, place, disingkat menjadi 4P.

1) Product (produk)

2) Price (harga)

3) Promotion (promosi)

4) Place (tempat/saluran distribusi) 


\section{Strategi Pemasaran}

Berikut strategi pemasaran berdasarkan unsur-unsur bauran pemasaran adalah sebagai berikut :

Strategi produk

Dalam bahasan ini akan diuraikan proses pengembangan dan pemasaran produk-produk baru dihubungkan dengan tujuh tahap siklus hidup suatu produk. Ketujuh tahap siklus hidup produk tersebut adalah :

a) Membangkitkan dan menyaring konsep atau gagasan, produk-produk baru dimulai dari gagasan atau konsep. Tahap pertama dalam mengembangkan produk baru mencakup membangkitkan dan menyarig konsep atau gagasan.

b) Perencanaan dan pengembangan produk dalam tahap ini meliputi evaluasi yang lebih mendalam, perencanaan, dan pengembangan konsep produk yang lolos dari proses penyaringan konsep atau gagasan.

c) Uji pemasaran atau stimulasi pasar dalam tahapan ini, reaksi konsumen terhadap produk diselidiki. Produkproduk diuji pasar di daerah tertentu untuk menentukan potensi penjualannya. Uji pasar ini didasarkan pada sampel kecil dari sebagian masyarakat konsumen potensial.

d) Tahap komersialisasi atau pengenalan, tahap ini merupakan tahap akhir dari proses pengembangan produk baru dan merupakan tahap awal dari daur hidup produk. Sasaran utama dalam produk ini adalah membuat konsumen mengetahui produk tersebut dan mencoba membelinya.

e) Tahap pertumbuhan pasar dalam tahap pertumbuhan, penjualan produk mulai meningkat secara cepat dan produk tersebut mulai member sedikit keuntungan. Pasar semakin luas disebabkan semakin meningkatnya pembelian ulang oleh pembeli sebelumnya dan pembeli-pembeli baru dalam jumlah besar yang dipengaruhi oleh para pembeli sebelumnya.

f) Tahap kejenuhan atau kedewasaan dalam tahap kejenuhan, pertumbuhan penjualan mulai berkurang atau melambat dan semakin lama semakin mendekati pertumbuhan nol.

Kebanyakan konsumen yang pernah melakukan pembelian produk mungkin akan melanjutkan pembelian produk tersebut, atau mungkin mulai mencoba produk merek lainnya.

g) Tahap penurunan atau penghapusan produk dalam tahap ini, pasar produk tidak normal lagi dan penjualan mulai turun secara cepat atau drastis. Dalam tahap ini produk mungkin dapat dihapus atau tidak diproduksi lagi.

\section{$>$ Strategi harga}

Terdapat tiga hal penting yang mempengaruhi strategi harga yaitu sebagai berikut:

a) Karakteristik konsumen

b) Karakteristik perusahaan

c). Karakteristik persaingan

\section{Strategi saluran distribusi}

Pilihan pasar, segmentasi pasar, dan target pasar sangat terkait dengan saluran distribusi. Dalam saluran langsung, pabrikasi atau perusahaan menjual secara langsung kepada pemakai akhir. Dalam saluran tidak langsung, pabrik atau perusahaan menggunakan satu atau lebih perantara untuk menjual produk ke pemakai akhir. Jenis-jenis perantara pemasaran, yaitu :
a) Perantara
b) Agen
c) Perwakilan perusahaan
d) Pedagang besar 
e) Pengecer

f) Pedagang perantara

g) Agen penjualan

h) Distributor atau perantara

i) Dealer

j) Pemborong

Strategi promosi

a) Periklanan

b) Promosi penjualan

c) Publisitas

d) Penjualan personal

Untuk mengukur capaian strategi menggunakan pelaporan pelaksanaan dari kegiatan - kegiatan yang ada maka dibentuklah suatu output - output untuk mengukur kinerja(Alimudin, 2017)

\section{$>$ Definisi Konsepsional}

Analisis SWOT merupakan cara untuk menganalisis strategi pemasaran perusahaan UD. Star Motor dalam lingkungan internal maupun eksternalnya, yang bertujuan untuk mendeteksi serta merumuskan kebijaksanaan yang sifatnya strategi bagi perusahaan. Adapun Implementasi strategi untuk bidang fungsi pemasaran yaitu dimulai dengan mempertimbangkan bauran pemasaran (marketing mix), yakni produk, harga, saluran distribusi, dan promosi. Bauran dari unsur-unsur pemasaran tersebut harus tepat, dan rencana-rencana dari setiap unsure tersebut juga harus tepat. Bauran pemasaran merupakan variabel yang dapat dikendalikan oleh organisasi perusahaan untuk melakukan penyesuaian-penyesuaian terhadap target pasar atau mempengaruhi target pasar tersebut. organisasi perusahaan harus mengembangkan strategi-strategi dengan mengsinkronisasikan unsurunsur bauran pemasaran untuk mencapai sasaran yang sama(Alimudin, 2015)

\section{$>$ Metode Penelitian}

\section{$>$ Jenis Penelitian}

Penelitian ini menggunakan metode penelitian deskriptif kualitatif. Penelitian deskriptif merupakan metode penelitian yang berusaha menggambarkan suatu objek sesuai dengan keadaan atau apa adanya.

\section{Fokus Penelitian}

Untuk memberikan gambaran yang lebih jelas mengenai objek yang diteliti maka penulis sampaikan bahwa fokus penelitian adalah terbatas pada analisis SWOT UD. Star Motor divisi onderdil motor. Adapun defenisi operasional dari variabel penelitian adalah sebagai berikut :

\section{A. Lingkungan Eksternal}

Analisa lingkungan eksternal akan dilakukan dengan mengamati baik lingkungan makro maupun lingkungan industri yakni sebagai berikut :

1) Lingkungan Makro

a) Elemen Perekonomian

b) Elemen Politik dan Legal

c) Elemen Sosial-Budaya

d) Elemen Lingkungan Teknologi

2) Lingkungan Industri 

a) Ancaman Pelaku Bisnis Baru
b) Ancaman Produk Substitusi
c) Kekuatan Tawar-Menawar Pembeli
d) Kekuatan Tawar-Menawar Pemasok
e) Persaingan Dalam Industri
b. Lingkungan Internal

B. Analisis internal akan dilakukan dengan pendekatan fungsional dan akan dibatasi pada fungsi pemasaran saja, melalui pendekatan bauran pemasaran 4 variabel yakni sebagai berikut :

1) Product (Produk)

2) Price (Harga)

3) Place (Tempat)

4) Promotion (Promosi)

\section{Jenis dan Sumber Data}

\section{a. Jenis Data}

Data yang dipakai dalam penelitian ini adalah data primer dan data sekunder. Data primer yaitu data yang diperoleh langsung dari responden dengan cara observasi, wawancara sesuai dengan keadaan yang sebenarnya. Data sekunder yaitu data yang dikerjakan oleh perusahaan itu sendiri, disini penulis mendapatkan data dari UD. Star Motor.

\section{b. Sumber Data}

Untuk menunjang pembahasan terhadap masalah yang dikemukakan diatas, maka diperlukan data meliputi :

1) Gambaran umum perusahaan

2) Struktur organisasi perusahaan

3) Data lain yang berhubungan dengan dengan penulisan skripsi ini

\section{Teknik Pengumpulan Data}

Dalam penelitian ini penulis mengumpulkan data dengan teknik sebagai berikut :

a. Penelitian lapangan (field work research) Yaitu pengumpulan data langsung yang menjadi objek penelitian untuk melihat dari dekat perusahaan tersebut, dengan menggunakan metode :

1) Pengamatan (observasi)

2) Wawancara (interview)

3) Kuesioner

b. Penelitian Kepustakaan (library research) Yaitu mengumpulkan data sekunder atau data yang diperoleh dari data yang telah dibukukan, baik berupa laporan-laporan maupun hasil penelitian terdahulu.

\section{$>$ Analisis SWOT}


Untuk menganalisis penentuan strategi menjadi jelas, ada sembilan macam matriks yang dapat digunakan yakni sebagai berikut :
a. Matriks Eksternal Factor Evaluation (EFE)
b. Matriks Internal Factor Evalution (IFE)
c. Matriks Competitive Profile (CP)
d. Matriks SWOT
e. Matriks Strategic Position and Action Evalution (SPACE)
f. Matriks Internal-Exsternal (IE)
g. Matriks Boston Consulting Group (BCG)
h. Matriks Grand Strategy
i. Matriks Quantitative Strategies Planning (QSP)

\section{$>$ Teknik Analisis Data}

Menurut Rangkuty (2006), analisis data yang digunakan untuk memecahkan masalah adalah sebagai berikut : a. Dalam sel Opportunities (O), dirumuskan beberapa peluang yang dihadapi oleh perusahaan. Hal ini harus mempertimbangkan deregulasi industry sebagai salah satu faktor strategis.

b. Dalam sel Threats (T), menentukan beberapa ancaman yang dihadapi perusahaan.

c. Dalam sel Strengths (S), menentukan beberapa ancaman yang dihadapi perusahaan.

d. Dalam sel Weaknesses (W), menentukan beberapa kelemahan yang masih membelit perusahaan.

e. Merumuskan beberapa kemungkinan alternatif strategi perusahaan

> Berdasarkan pertimbangan kombinasi empat peluang faktor strategi tersebut, yang terdiri dari :

\section{1) Strategi $\mathrm{SO}$}

Strategi ini dibuat berdasarkan suatu jalan pikiran, yaitu bagaimana perusahaan menggunakan seluruh kekuatan untuk memanfaatkan peluang.

2) Strategi ST

Strategi ini untuk menggunakan kekuatan yang dimiliki perusahaan dengan cara menghindari ancaman.

3) Strategi WO

Strategi ini diterapkan dengan memanfaatkan peluang yang ada dan mengatasi kelemahan-kelemahan yang dimiliki.

4) Strategi WT

Strategi ini didasarkan pada kegiatan yang bersifat defensif dan ditujukan meminimalkan kelemahan yang ada serta menghindari ancaman.

Selanjutnya dengan menggunakan faktor strategis baik internal maupun eksternal sebagaimana telah dijelaskan dalam tabel EFAS dan IFAS, lalu melanjutkan tahap satu sampai dengan enam diatas. Transfer peluang dan ancaman (tahap satu dan dua) dari tabel EFAS serta tambahkan kekuatan dan kelemahan (dari tahap ketiga dan keempat). Berdasarkan pendekatan tersebut, dapat dibuat berbagai kemungkinan alternatif strategi (SO, ST, WO, WT) 


\section{$>$ Matriks SWOT UD. Star Motor}

Disusun berdasarkan analisis internal (kekuatan dan kelemahan) dan eksternal (peluang dan ancaman) UD. Star Motor. Analisis internal dilakukan dengan membuat matrik IFAS (Internal Factors Analysis Summary) dan matrik EFAS (Eksternal Factors Analysis Summary). Setelah diketahui nilai dari matrik IFAS dan matrik EFAS, maka dapat dilihat posisi perusahaan berdasarkan nilai matrik IFAS dan matrik EFAS pada matrik IE (Internal Esternal) yang digunakan untuk menentukan strategi pemasaran yang dapat digunakan oleh perusahaan(Alimudin \& Yoga, 2015).

Analisa SWOT yang ada di UD. Star Motor

Strengths (kekuatan)

- Perusahaan memberikan potongan penjualan

- Pemberian bonus kepada para konsumen

- Pelayanan yang ramah dan cepat

- Produk motor yang dijual bervariasi

- Geografis di Indonesia cocok apabila di pakai jenis onderdil motor, khususnya di daerah terpencil

- Merupakan kendaraan pribadi yang sesuai dengan kondisi perekonomian di Masyarakat dari segi harga dan kualitas (harga dapat di jangkau oleh kalangan menengah ke bawah)

- Image irit di masyarakat masih melekat, sehingga masih di gemari (lebih irit dari segi bahan bakar dan onderdiel)

Weakness (kelemahan)

- Tidak selalu memberikan bonus kepada pegawai

- Kurangnya sales promotion

- Sasaran promosi yang tergantung dari leasing dan pusat

- Penerapan teknologi yang kurang

- Muncul merek sepeda motor cina (mocin) 
Opportunies (kesemptan / peluang)

- Banyaknya peminat kendaraan motor

- Tingkat pertumbuhan pasar yang cepat

- Pangsa pasar yang besar

- Hubungan yang baik dengan konsumen

- Memiliki tempat / pabrik perakitan sendiri

- Memiliki pabrik suku cadang / spare part

Treaths (ancaman)

- Banyaknya pesaing dalam penjualan motor

- Lokasi pesaing lebih strategis

- Pesaing lebih sering melakukan promosi

- Beberapa stock jenis tertentu umumnya terbatas

$>$ Bobot Penilaian:

- Ukuran pembobotan :

$0 \quad=$ Sedikit penting

$1=$ Agak penting

$0,1=$ Penting

$0,15=$ Sangat penting

- Ukuran Rating kekuatan dan kelemahan :

$1=$ Sedikit kuat / lemah / mengancam

2 = Agak kuat / lemah / mengancam

3 = Kuat / lemah / mengancam

$4=$ Sangat kuat / lemah / mengancam 


\section{Analisis Internal}

Disusun untuk merumuskan faktor-faktor strategis internal perusahaan dalam kerangka strength and weakness perusahaan. Diidentifikasi dalam suatu tabel IFAS, seperti yang dapat dilihat pada tabel 1.

\section{IFAS UD. Star Motor}

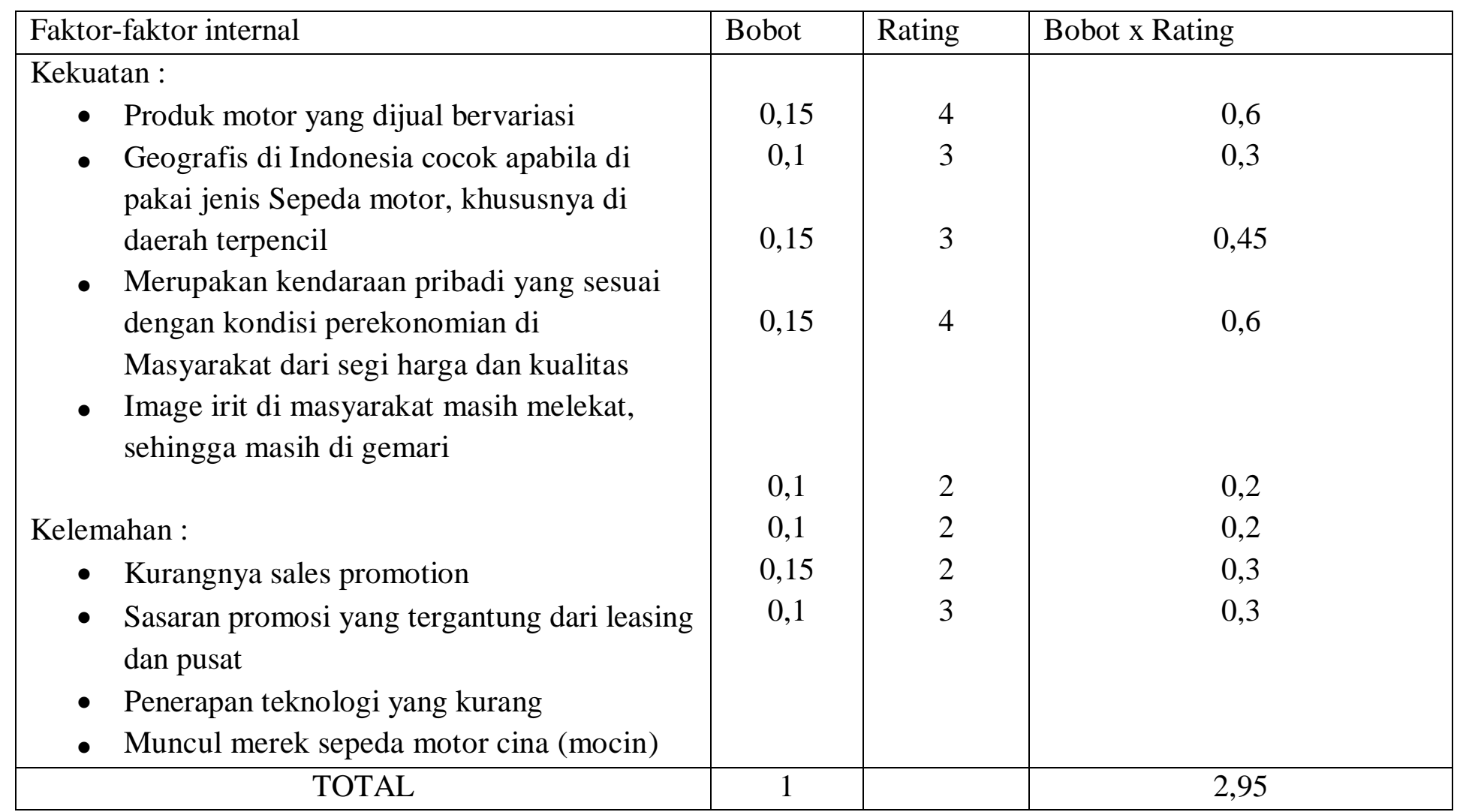

Berdasarkan tabel 1, total nilai matrik IFAS UD. Star Motor adalah sebesar 2.95. Dalam matrik IE nilai 2.95 masuk dalam kategori rata-rata dalam kekuatan internal. Selisih $\mathrm{A}-\mathrm{W}=1.95-1=0.9$

\section{Analisis Eksternal}

Disusun untuk merumuskan peluang dan ancaman yang ada, sehingga dapat mengoptimalkan peluang yang ada dan menghindari ancaman yang ada.

Diidentifikasi dalam suatu tabel EFAS, seperti yang dapat dilihat pada tabel 2. 
EFAS UD. Star Motor

\begin{tabular}{|l|c|c|c|}
\hline Faktor-faktor Eksternal & Bobot & Rating & Bobot x Rating \\
\hline Peluang : & 0,15 & 4 & 0,6 \\
- Banyaknya peminat kendaraan motor & 0,15 & 4 & 0,6 \\
- Tingkat pertumbuhan pasar yang cepat & 0,15 & 4 & 0,6 \\
- Memiliki tempat / pabrik perakitan sendiri & & 0,3 \\
$\quad$ suku cadang / spare part & 0,1 & 3 & 0,2 \\
- Pangsa pasar yang besar & & & 0,3 \\
Ancaman : & 0,1 & 2 & 0,2 \\
- Banyaknya pesaing dalam penjualan motor & 0,15 & 2 & 0,2 \\
- Lokasi pesaing lebih strategis & 0,1 & 2 & 3 \\
- Pesaing lebih sering melakukan promosi & 0,1 & 2 & \\
$\quad$ Beberapa stock jenis tertentu umumnya & & & \\
\hline$\quad$ TOTAL & 1 & & \\
\hline
\end{tabular}

Berdasarkan tabel 2, total nilai matrik EFAS UD. Star Motor adalah sebesar 3. Dalam matrik IE nilai 3 masuk dalam kategori tinggi dalam kekuatan ekternal. Selisih $\mathrm{O}-\mathrm{T}=2.1-9=1.2$

Berdasarkan hasil-hasil yang didapat dari analisis internal dan eksternal pada Tabel seperti dituliskan di atas, hasilnya dapat dirangkum sebagai berikut:

1. Skor Total Kekuatan 1.95

2. Skor Total Kelemahan 1

3. Skor Total Peluang 2.1

4. Skor Total Ancaman 0.9

\section{Koordinat Analisis Internal}

(Skor total Kekuatan - Skor Total Kelemahan) $=$

$(1.95-1)=0,95$

Koordinat Analisis Eksternal

$($ Skor total Peluang - Skor Total Ancaman $)=$

$(2.1-0.9)=1.2$ 


\section{Gambar 5.1}

\section{Posisi UD Star Motor Surabaya}

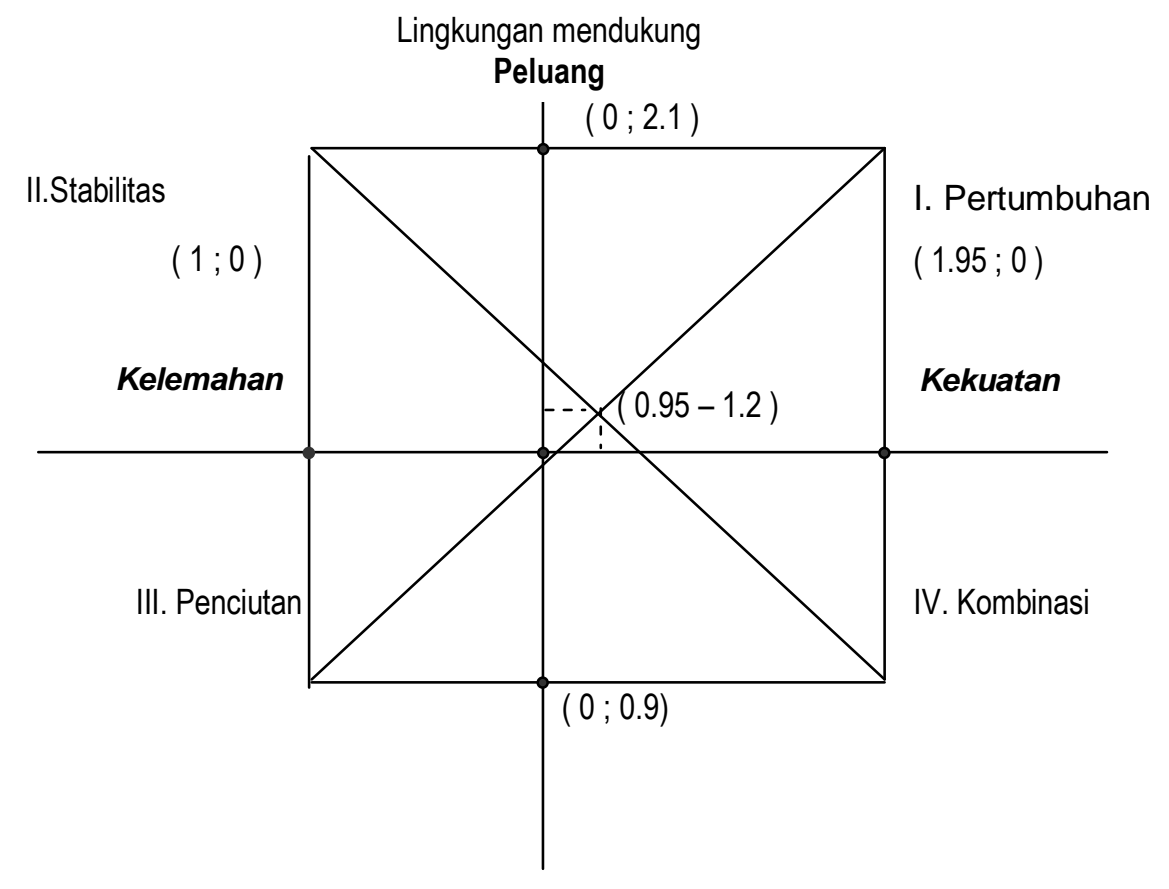

Ancaman

Lingkungan Kurang mendukung

\section{Matrik IE ( Internal EksternaI )}

Analisis internal UD. Star Motor mempunyai total nilai 2.95, dan analisis eksternal mempunyai total nilai 3, Untuk lebih jelasnya dapat dilihat pada tabel 3 .

\section{TABEL 3}

\section{Matrik IE UD. Star Motor}

$\begin{array}{lcc}\text { Tinggi } & \text { Rata-rata } & \text { Lemah } \\ (3,0-4,0) & (2,0-2,99) & (1,0-1,99)\end{array}$

Tinggi

$(3,0-4,0)$

Sedang

$(2,0-2,99)$

Rendah

$(1,0-1,99)$

\begin{tabular}{|l|l|l|}
\hline 1 & $\begin{array}{l}2 \\
\text { UD . STAR } \\
\text { MOTOR }\end{array}$ & 3 \\
\hline 4 & 5 & 6 \\
\hline 7 & 8 & 9 \\
\hline
\end{tabular}


Berdasarkan tabel 3, UD. Star Motor berada dalam sel 2 yang berarti UD. Star Motor berada dalam strategi pertumbuhan melalui

integrasi horizontal. Strategi pemasaran yang dapat digunakan dalam strategi pertumbuhan melalui integrasi horizontal adalah dengan memperluas perusahaan yang dapat dilakukan dengan cara membangun lokasi lain dan meningkatkan jenis

produk untuk meningkatkan penjualan dan laba. Setelah diketahui matrik IFAS, matrik EFAS dan matrik IE, maka dapat

disusun matrik SWOT. Matrik SWOT disusun untuk menggambarkan bagaimana peluang dan ancaman eksternal yang dihadapi perusahaan dapat disesuaikan dengan kekuatan dan kelemahan yang dimiliki perusahaan. Matrik SWOT dapat

menghasilkan empat set strategi yang dapat dilakukan UD. Star Motor. Untuk lebih jelasnya dapat dilihat pada tabel 4. 


\section{Tabel 4}

\section{Matrik SWOT UD . Star Motor}

\begin{tabular}{|c|c|c|}
\hline EFAS & $\begin{array}{l}\text { Strengths : } \\
\text { - } \text { Produk motor yang dijual bervariasi } \\
\text { - } \text { Geografis di Indonesia cocok apabila di } \\
\text { pakai jenis Sepeda motor, khususnya di } \\
\text { daerah terpencil } \\
\text { - } \text { Merupakan kendaraan pribadi yang } \\
\text { sesuai dengan kondisi perekonomian di } \\
\text { Masyarakat dari segi harga dan kualitas } \\
\text { - Image irit di masyarakat masih melekat, } \\
\text { sehingga masih di gemari }\end{array}$ & $\begin{array}{l}\text { Weakness : } \\
\text { - } \text { Kurangnya sales promotion } \\
\text { - } \text { Sasaran promosi yang tergantung dari } \\
\text { leasing dan pusat } \\
\text { - } \text { Penerapan teknologi yang kurang } \\
\text { - } \text { Muncul merek sepeda motor cina } \\
\text { (mocin) }\end{array}$ \\
\hline $\begin{array}{l}\text { Opportunies : } \\
\text { - } \text { Banyaknya peminat kendaraan motor } \\
\text { - Tingkat pertumbuhan pasar yang cepat } \\
\text { - Memiliki tempat / pabrik perakitan } \\
\text { - } \text { sendiri suku cadang / spare part } \\
\text { Pangsa pasar yang besar }\end{array}$ & $\begin{array}{l}\text { Strategi SO : } \\
\text { 1. }(0.6,0.6)=\text { (kuat, kuat }) \\
\text { 2. }(0.3,0.6)=(\text { lemah, kuat }) \\
\text { 3. }(0.45,0.6)=(\text { kuat }, \text { kuat }) \\
\text { 4. }(0.6,0.3)=(\text { kuat, lemah }) \\
\text { Rata-rata }:(0.487,0.525)\end{array}$ & $\begin{array}{l}\text { Strategi WO : } \\
\text { 1. }(0.2,0.6)=(\text { lemah, kuat }) \\
\text { 2. }(0.2,0.6)=(\text { lemah }, \text { kuat }) \\
\text { 3. }(0.3,0.6)=(\text { lemah }, \text { kuat }) \\
\text { 4. }(0.3,0.3)=(\text { lemah, lemah }) \\
\text { Rata-rata }:(0.25,0.525)\end{array}$ \\
\hline $\begin{array}{l}\text { Treaths : } \\
\text { - } \text { Banyaknya pesaing dalam penjualan } \\
\text { motor } \\
\text { - Lokasi pesaing lebih strategis } \\
\text { - Pesaing lebih sering melakukan promosi } \\
\text { - Beberapa stock jenis tertentu umumnya } \\
\text { terbatas }\end{array}$ & $\begin{array}{l}\text { Strategi ST: } \\
\text { 1. }(0.6,0.2)=(\text { kuat }, \text { lemah }) \\
\text { 2. }(0.3,0.3)=(\text { lemah, lemah }) \\
\text { 3. }(0.45,0.2)=(\text { kuat }, \text { lemah }) \\
\text { 4. }(0.6,0.2)=(\text { kuat, lemah }) \\
\text { Rata-rata }:(0.487,0.225)\end{array}$ & $\begin{array}{l}\text { Strategi WT }: \\
1 .(0.2,0.2)=(\text { lemah }, \text { lemah }) \\
\text { 2. }(0.2,0.3)=(\text { lemah }, \text { lemah }) \\
\text { 3. }(0.3,0.2)=(\text { lemah }, \text { lemah }) \\
\text { 4. }(0.3,0.2)=(\text { lemah }, \text { lemah }) \\
\text { Rata-rata }:(0.25,0.225)\end{array}$ \\
\hline
\end{tabular}




\section{Kesimpulan}

Berdasarkan pembahasan pada bab sebelumnya, maka penulis dapat memberikan kesimpulan :

1. Dari analisis matrik BCG, UD. Star Motor berada dalam kuadran stars, strategi pemasaran yang dapat digunakan adalah dengan melakukan investasi dan bekerja sama dengan pemasok untuk membuka cabang UD. Star Motor di lokasi lain dan melaksanakan upaya meminimalkan biaya dan operasi yang tidak efisien agar tetap mempunyai cash flow yang kuat.

2. Dari analisis $\mathrm{SWOT}$ diketahui nilai $\mathrm{S}<\mathrm{O}$, strategi yang dapat digunakan adalah membuka lokasi baru, dan memberikan potongan penjualan yang lebih besar jika konsumen melakukan pembelian ulang. Nilai $\mathrm{W}<\mathrm{O}$, strategi yang dapat digunakan adalah dengan memberikan bonus secara intensif kepada pegawai, dan menambah tenaga pemasaran. Nilai S>T, strategi yang dapat digunakan adalah dengan terus meningkatkan kualitas dan mutu pelayanan dan dengan membangun gudang tempat penyimpanan onderdil yang siap dijual. Nilai $\mathrm{W}>\mathrm{T}$, strategi yang dapat digunakan adalah dengan terus meningkatkan kegiatan-kegiatan promosi dan dengan meminimalkan biaya dan operasi yang tidak efisien. 


\section{ANALISIS SWOT DALAM MENENTUKAN STRATEGI \\ PEMASARAN ONDERDIL PADA UD. STAR MOTOR}

Analisis SWOT Dalam Menentukan Strategi Pemasan Onderdil Motor Pada UD. Star Motor di Surabaya. dibawah kepemimpinan Bpk. Yeffry sebagai General Manager dan Bpk. David Nyoto Gunawan sebagai sebagai Assisten General Manager.

Penelitian ini bertujuan untuk mengidentifikasi dan menjelaskan kekuatan dan kelemahan (lingkungan internal) serta peluang dan ancaman (lingkungan eksternal) serta merumuskan srtategi pemasaran onderdil motor yang tepat melalui analisis SWOT (Strengths, Weaknesess, Opportunities, dan Threats) pada UD.Star Motor.

Hasil penelitian yang dilakukan penulis pada UD. Star Motor adalah dengan menggunakan alat analisis SWOT, maka UD. Star Motor dapat menggunakan saran alternatif strategi-strategi yang telah dihitung dari analisis SWOT diatas sebagai berikut :

$>$ A. Strategi Strength - Opportunities

1) Pertahankan dan tingkatkan kualitas produk maupun pelayanan purna jual

2) Pengembangan pasar menengah kebawah

3) Mengadakan kegiatan eksibisi

B. Strategi Weaknesses - Opportunities

1) Promosi yang terarah

2) Promosi yang lebih gencar dengan mengadakan, mengikuti atau sebagai sponsor di berbagai event, promosi melalui media cetak dan media jejaring sosial.

3) Menambah sub dealer

C. Strategi Strenght - Threats

1) Mengembangkan daya saing

2) Meningkatkan hubungan baik dengan pelanggan

D. Strategi Weaknesses - Threats

1) Memperluas area promosi dengan membuka outlet - outlet untuk memperluas jaringan penjualan

2) Menambah variasi penjualan dealer seperti menjual aksesoris motor yang sedang trend di masyarakat

3) Memberikan diskon harga spare partbagi konsumen yang loyal

\section{Daftar Pustaka}

Alimudin, A. (2015). Strategi pengembangan minat wirausaha melalui proses pembelajaran. E-Jurnal Manajemen KINERJA, 1(1).

Alimudin, A. (2017). ANALISIS PENCAPAIAN STRATEGI MENGGUNAKAN BALANCED SCORECARD. Jurnal Pendidikan Ekonomi \& Bisnis (Edisi Elektronik), 5(2), 178-194.

Alimudin, A., \& Yoga, H. (2015). Strategi meningkatkan loyalitas pelanggan pada usaha kecil produk makanan ringan di surabaya. Proceeding Seminar Nasional \& Call for Papers (SCA 5), 1-12.

Kotler, P., \& Keller, K. L. (2009). Manajemen Pemasaran (judul asli: Marketing Management) (13th ed.). Jakarta: Airlangga.

Kotler, P. (2000). Marketing Management, Millenium Edition. Marketing Management, 23(6), $188-193$. https://doi.org/10.1016/0024-6301(90)90145-T 
